\title{
Investigating a transcriptomic approach on marine mussel hemocytes exposed to carbon nanofibers: An in vitro/in vivo comparison
}

\author{
Andrew Barrick ${ }^{\mathrm{a}, *}$, Nicolas Manier ${ }^{\mathrm{b}}$, Pierre Lonchambon ${ }^{\mathrm{c}}$, Emmanuel Flahaut ${ }^{\mathrm{c}}$, Nisrine Jrad $^{\mathrm{d}}$, \\ Catherine Mouneyrac ${ }^{\mathrm{a}}$, Amélie Châtel ${ }^{\mathrm{a}}$ \\ ${ }^{a}$ UBL (Université Bretagne et Loire), Mer Molécules Santé (MMS), Université Catholique de l'Ouest, 3 place André Leroy, BP10808, 49008, Angers Cedex 01, France \\ ${ }^{\mathrm{b}}$ INERIS (Institut National de l'Environnement Industriel et des Risques), $\backslash$ Expertise and assay in ecotoxicology unit, Parc Technologique ALATA, 60550, Verneuil-en- \\ Halatte, France \\ ${ }^{\mathrm{c}}$ CIRIMAT, Université de Toulouse, CNRS, INPT, UPS, UMR CNRS-UPS-INP N ${ }^{\circ}$ 085, Université Toulouse 3 Paul Sabatier, Bât. CIRIMAT, 118, route de Narbonne, \\ 31062, Toulouse cedex 9, France \\ d LARIS (Laboratoire Angevin de Recherche en Ingénierie des Systèmes), EA-7315, Université Catholique de l'Ouest, 3 place André Leroy, BP10808, 49008, Angers Cedex \\ 01, France
}

\begin{abstract}
Manufactured nanomaterials are an ideal test case of the precautionary principle due to their novelty and potential environmental release. In the context of regulation, it is difficult to implement for manufactured nanomaterials as current testing paradigms identify risk late into the production process, slowing down innovation and increasing costs. One proposed concept, namely safe(r)-by-design, is to incorporate risk and hazard assessment into the design process of novel manufactured nanomaterials by identifying risks early. When investigating the manufacturing process for nanomaterials, differences between products will be very similar along key physicochemical properties and biological endpoints at the individual level may not be sensitive enough to detect differences whereas lower levels of biological organization may be able to detect these variations. In this sense, the present study used a transcriptomic approach on Mytilus edulis hemocytes following an in vitro and in vivo exposure to three carbon nanofibers created using different production methods. Integrative modeling was used to identify if gene expression could be in linked to physicochemical features. The results suggested that gene expression was more strongly associated with the carbon structure of the nanofibers than chemical purity. With respect to the in vitro/in vivo relationship, results suggested an inverse relationship in how the physicochemical impact gene expression.
\end{abstract}

\section{Introduction}

The assessment of environmental risk of manufactured nanomaterials (MNMs), or nanomaterials designed for a specific purpose, in the marine environmental is more of a hypothesis than an established risk (Matranga and Corsi, 2012). Ecosystems are also influenced by multiple stressors (e.g. urban and industrial runoff) often from nonpoint sources limiting the ability to prove that MNMs pose significant risks. To assess the potential environmental risk of emerging contaminants, environmental programs, like the European Water Framework Directive (WFD) which follows the precautionary principle, aim to focus on prevention rather than mitigation. In this sense, hazard assessment aims to identify the associated environmental impact with MNMs prior to their use and, in some cases, eventual release into the environment (Canesi et al., 2008a). In the context of regulation, it is difficult to implement this approach as current testing paradigms identify risk late into the production process, slowing down innovation and increasing costs. To address this, one of the proposed approaches, safe(r)-by-design (SbD), aims to incorporate hazard assessment into the design process of novel MNMs (Schwarz-plaschg et al., 2017). The application of SbD to MNMs was developed in the European FP7 projects NANoREG and Prosafe and is being expanded on in the European Horizon 2020 project NanoReg2. The objectives of an SbD approach is to apply the precautionary principle early in the production/innovation process and in this way, hazards and risks can be identified early and strategies to mitigate their effects without placing significant burdens for industry(Kraegeloh et al., 2018). It is important to note however that the aim of SbD is not to completely remove the risk but to find ways to lower the risk without hindering the performance of the product.

To adequately implement a SbD approach, rapid and cost-effective 
techniques need to be developed to quickly screen the potential hazards of products. Testing that focuses on sub-individual multi-endpoint responses may provide an ideal starting point for developing a rapid prescreening strategy for MNMs (Moore, 2006). In the context of SbD, MNMs produced by a company are also likely to have minimal differences which may make individual endpoints (e.g. growth, mortality...) unsuitable in accurately detecting differences in the potential adverse effects between MNMs. As a result, testing at lower levels (e.g. molecular or biochemical) of biological organization may be more appropriate in discriminating between MNMs that are similar along many key physicochemical properties. Due to the rapid rate that new nanomaterials are being produced, as well as legislative and public concerns over the ethics of animal testing promoting the use of the 3 R's (Replacement, Reduction and Refinement), in $v$ itro t esting that $\mathrm{c}$ an be adapted to a high throughput screening (HTS) approach can provide a relatively low cost means of screening a large number of chemical in a short amount of time (Barrick et al., 2017; Fenwick et al., 2009). One of the challenges however, is that in vitro testing has not been adequately demonstrated (to date) to be a suitable alternative to in vivo testing for marine environmental risk assessment.

Transcriptomic tools could be considered as a suitable "HTS approach" for ecotoxicity as it allows for an improved understanding of the molecular mechanisms underlying responses to environmental contaminants and can screen a large number of endpoints in a short amount of time (Snape et al., 2004). However, it is important to note that for marine species there is limited knowledge for genes, limiting the number of available endpoints for testing (Revel et al., 2017). Transcriptomics could also provide k nowledge on mode of actions (MoAs) for MNMs and represent a way to predict toxicity before stronger effects occur at higher levels of biological organization (Revel et al., 2017). In the context of integrating ecotoxicological hazards into aSbD approach, this is could be ideal in discriminating between similar products.

In this sense, the present study implemented a transcriptomic approach through real-time quantitative PCR (qPCR) on a primary cell culture of $M$. edulis hemocytes to measure the ecotoxicity of 3 carbon nanofibers (CNFs), GANF, GATam and GANFg, under development by an industrial partner. The objectives of the study were i) to identify the impact of these products on gene expression, ii) identify if the CNFs could be discriminated from one another through gene expression, and iii) if in vitro testing could be considered a suitable alternative testing strategy. To determine if the in vitro exposure could adequately be used as an alternative testing strategy, an in vivo exposure was also conducted for comparison. The aim was not to have equivalent values between in vitro and in vivo testing but to determine if both testing strategies developed the same conclusions. After a 24-hour exposure, expression levels of a battery of genes implicated in xenobiotic transport/transformation, oxidative stress, metabolic activity, cell transport, cytoskeleton and cell cycle control were investigated. These endpoints were selected have been used previously in to investigate the effects of nanomaterials on gene expression in M. edulis (Châtel et al., 2018). The 24-hour exposure was selected as previous studies have shown this to be the optimal duration to maintain Mytilus hemocytes in cell culture and previous study have shown hemocytes, in vitro and in vivo, to respond to MNMs during this time period (Barrick et al., 2018; Canesi et al., 2008b; Gagné et al., 2008; Katsumiti et al., 2014).

\section{Material and methods}

\subsection{Nanomaterials used in the study}

Three CNFs (GANF, GATam and GANFg) were provided by Grupo Antolin. The CNFs are an industrial grade product for commercial use in automobile parts. Grupo Antolin initially produced GANF through catalytic vapor deposition (CVD) using a natural gas and sulfur feed stock at temperatures greater than $1100{ }^{\circ} \mathrm{C}$ in a floating catalyst reactor
Table 1

Physico-chemical properties reported by the industrial partner.

\begin{tabular}{lllll}
\hline Measured property & Unit & GANF & GANFg & GATam \\
\hline Fiber diameter (TEM) & $\mathrm{nm}$ & $20-80$ & $20-80$ & $20-80$ \\
Carbon purity (TGA) & $\%$ & $>85$ & $>99$ & $>80$ \\
Apparent density & $\mathrm{g} / \mathrm{cc}$ & $\sim 0.06$ & $\sim 0.08$ & $\sim 0.08$ \\
Specific surface area (BET $\left.\mathrm{N}_{2}\right)$ & $\mathrm{m}^{2} / \mathrm{g}$ & $100-170$ & $70-90$ & $70-140$ \\
Graphitization degree (XRD) & $\%$ & $\approx 70$ & $\approx 90$ & $\approx 60$ \\
Electrical resistivity & $\Omega-* \mathrm{~m}$ & $1 * 10^{-3}$ & $1 * 10^{-4}$ & $1 * 10^{-3}$ \\
\hline
\end{tabular}

(Vera-Agullo et al., 2007; Weisenberger et al., 2009). Deposition of graphene layers is promoted by metallic nickel while catalytically inactive NiS allows for the formation of helical-ribbons with a stacked cup structure. To scale up production, a new method was developed to produce higher volumes of CNFs. This is the process used to create GATam, which has slight differences in physicochemical properties when compared to GANF. GANFg CNFs are created by super heating GANF at $2500^{\circ} \mathrm{C}$, which decreases the interlayer spacing in the CNF and removes nickel and sulfur impurities (Weisenberger et al., 2009). Physicochemical differences measured by Grupo Antolin are summarized in Table 1.

\subsection{Preparation and characterization of nanomaterials}

Nanomaterial suspensions were prepared following the NANoREG Standard Operating Procedure (SOP) (Jensen et al., 2011). Briefly, $15.36 \mathrm{mg}$ of nanomaterial powder was measured into a $20 \mathrm{~mL}$ ScintBurk glass vial (WHEA989581; Wheaton Industries Inc.) which is prewet with $30 \mu \mathrm{L}$ of absolute ethanol. The volume was adjusted to $6 \mathrm{~mL}$ with $0.05 \%$ Bovine Serum Albumin (BSA)-water (w/v) to achieve a final concentration of $2.56 \mathrm{mg} / \mathrm{mL}$. The suspension was then placed in an ice-water bath solution and sonicated using a Branson-S450 sonicator at $10 \%$ amplitude for $16 \mathrm{~min}$. The suspension was left on ice for 10 min prior to use.

To characterize the ENM behavior, suspensions were diluted to $25.6 \mathrm{mg} / \mathrm{L}$ in BSA stock suspension, cell culture media and in 30 p.s.u. (practical salt units) of artificial sea water (ASW), Tropic Marine, in $20 \mathrm{~mL}$ Scint-Burk glass vials and maintained at test conditions. This concentration was selected as it was found to achieve reliable results. Dynamic light scattering (DLS) and zeta potential (Malvern ZS90) was measured at $0,2,4,6$ and $24 \mathrm{~h}$ for each suspension to characterize the behavior of the nanomaterials over the duration of the experiment. Due to high ionic strength, zeta potential could not reliably be measured in cell culture media and ASW.

Transmission Electron Microscopy (TEM) was also used for each suspension to characterize the relative particle sizes of the ENMs. TEM (JEOL JEM 1400 plus @120kV, Japan) was used to visualize morphology of CNFs in the stock suspensions, culture media and artificial sea water. Carbon-coated grids were hydrophilized using a glow discharge apparatus (K100X, Emitech, UK). The glow discharge was performed for $180 \mathrm{~s}$ at an air pressure of $10^{-1} \mathrm{mbar}$ and an electric current of $40 \mathrm{~mA}$. This treatment was applied to TEM grids prior to the suspension deposition as it prevents most of the artefactual agglomeration phenomenon during the drying of the suspensions on the TEM grids (Dubochet et al., 1982).

CNFs suspensions were also analyzed using a Tecan Sunrise spectrometer to measure optical density as an approximation of stability over the duration of the experiment. Each suspension was measured across the visible light wavelength to determine which wavelength yielded the highest value. It was identified that a $340 \mathrm{~nm}$ wavelength yielded the highest absorbance values for all three CNFS. $60 \mu \mathrm{L}$ of suspension was taken from the surface of the liquids and triplicates were measured using a 96-well plate for all time points. The results were then normalized using a blank for each media suspension and values at each time point were adjusted relative to the start of the experiment. 
Raman spectroscopy was performed using a confocal Jobin Yvon LABRAM HR800 spectrometer (red laser at $633 \mathrm{~nm}$ ) using a maximum power of $5 \mathrm{~mW}$ with a spot size of $c a .1 \mu \mathrm{m}$. Ten accumulations of $5 \mathrm{~s}$ were acquired. Irradiation of the samples started $30 \mathrm{~s}$ before acquisition to limit the possible interference with fluorescence. 5 spectrums were obtained in 5 different areas of each sample.

\subsection{Hemocyte collection and establishment of primary cell culture}

M. edulis individuals of the same size $(4.2 \pm 0.23 \mathrm{~cm})$ were collected from a relatively clean sight, Saint-Cast-le-Guildo $\left(48^{\circ} 37^{\prime} 48^{\prime \prime} \mathrm{N}\right.$ $2^{\circ} 15^{\prime} 24^{\prime \prime} \mathrm{W}$ ), previously identified as suitable for experimental research (Chevé et al., 2014). Sampling was conducted in late fall to avoid the reproductive period, which would potentially influence results. Mussels were placed in artificial sea water $\left(30\right.$ p.s.u., at $15{ }^{\circ} \mathrm{C}$ with a 12 -hour light/day cycle) for a 2-day acclimation period prior to testing.

A primary cell culture on $M$. edulis hemocytes was established following the methodology described in (Barrick et al., 2018).A 23-guage, $2 \mathrm{~mL}$ syringe containing $0.1 \mathrm{~mL}$ of Alseve (ALS) buffer $\left(20.8 \mathrm{~g} . \mathrm{L}^{-1}\right.$ glucose, 8 g.L $\mathrm{L}^{-1}$ sodium citrate, 3.36 g.L $\mathrm{L}^{-1}$ EDTA, 22.5 g.L $\mathrm{L}^{-1} \mathrm{NaCl}, \mathrm{pH}$ 7.0) was used to extract the hemolymph (Cao et al., 2003). After aspirating hemolymph from 5 organisms, the needle was removed from the syringe and the contents were filtered through a $70 \mu \mathrm{m}$ filter into a falcon tube maintained at $4{ }^{\circ} \mathrm{C}$. After extracting hemolymph from 40 mussels the total volume was recorded.

Cell viability and cell concentration was then recorded through trypan blue exclusion. Hemocyte concentration was diluted to $1 \times 10^{6}$ cells. $\mathrm{mL}^{-1}$ using the ALS solution. $200 \mu \mathrm{L}$ of hemolymph was then seeded into a 96-well microplate $\left(2 \times 10^{5}\right.$ cells/well). The plate was then placed into an incubator at $18{ }^{\circ} \mathrm{C}$ for $30 \mathrm{~min}, 3.5 \% \mathrm{CO}_{2}$. After $30 \mathrm{~min}$, hemolymph was aspirated and replaced with adjusted Leibovitz L-15 medium (20.2 g.L $\mathrm{L}^{-1} \mathrm{NaCl}, 0.54$ g.L ${ }^{-1} \mathrm{KCl}, 0.6$ g.L $\mathrm{L}^{-1} \mathrm{CaCl}_{2}, 1$ g.L $\mathrm{L}^{-1}$ $\mathrm{MgSO}_{4}, 3.9$ g.L ${ }^{-1} \mathrm{MgCl}_{2}, 100$ units. $\mathrm{mL}^{-1}$ penicillin $\mathrm{G}, 100 \mu \mathrm{g} . \mathrm{mL}^{-1}$ streptomycin, $1 \%$ gentamycin, $10 \%$ glucose and $10 \%$ Fetal Bovine Serum (FBS), pH 7.0). Cells were left to adhere overnight prior to exposure.

\subsection{In vitro exposure}

Cell quality and attachment was visually confirmed the next day prior to ENM exposure using an inverted confocal microscope. Cell culture media was then refreshed with cell culture media containing ENMs in suspension $\left(0.01,0.1\right.$ and $\left.1 \mathrm{mg} . \mathrm{L}^{-1}\right)$ with three replicates per test concentration. These concentrations were selected as they are within the range of previous test concentrations used with Mytilus hemocytes (Canesi et al., 2008b). The cell culture was then returned to the incubator for $24 \mathrm{~h}$. After $24 \mathrm{~h}$, the media was removed and the cells were washed twice with PBS $(1,100 \mathrm{mOSM}) .50 \mu \mathrm{L}$ of trypsin was then added for to each well to detach the cells. After $5 \mathrm{~min}$, detachment was confirmed using an inverted confocal microscope after gently mixing the solution with a $20 \mu \mathrm{L}$ pipette. $150 \mu \mathrm{L}$ of cell culture media containing $10 \%$ FBS was then added to arrest trypsin activity. The cells were then collected in an Eppendorf tube and centrifuged at $500 \mathrm{~g}$ for 5 min at $4{ }^{\circ} \mathrm{C}$ to pellet the cells. Cell culture media was removed and the cells were washed with PBS $(1,100 \mathrm{mOsm})$. This step was repeated twice, after which the cell pellet was stored at $-80^{\circ} \mathrm{C}$ prior to analysis.

\subsection{In vivo exposure}

60 Mussels were placed in four $12 \mathrm{~L}$ aquariums (1.25 mussels. $\mathrm{L}^{-1}$ ) and maintained in the same conditions as the acclimation period. ENMs were spiked once into each aquarium at the three test concentrations ( $0.01,0.1$ and $1 \mathrm{mg} . \mathrm{L}^{-1}$ ) with 15 organisms per test concentration. Organisms were exposed for $24 \mathrm{~h}$, unfed and oxygenated using a glass Pasteur pipette, after which hemolymph was pooled for each test concentration following the previously described method.

\section{6. $q P C R$ assay}

\subsubsection{RNA extraction}

RNA extraction was conducted using a previously defined protocol (Châtel et al., 2018). Briefly, the hemocytes were ground in TRIzol Reagent $^{\circledR}$ (Ref: 15596026, Invitrogen ${ }^{\mathrm{Tm}}$ ) $1 \mathrm{ml}$ per $100 \mathrm{mg}$ of cells. Centrifugation $\left(12,000 \mathrm{~g}\right.$ for $10 \mathrm{~min}$ at $4^{\circ} \mathrm{C}$ ) was then used to suppress cellular debris. $0.2 \mathrm{~mL}$ Chloroform per $1 \mathrm{~mL}$ of TRIzol was added to the supernatant and shaken vigorously prior to centrifugation $(12,000 \mathrm{~g}$ for $15 \mathrm{~min}$ at $4^{\circ} \mathrm{C}$ ) to ensure a phase separation with the clear upper aqueous phase, containing RNA, being collected. $0.5 \mathrm{~mL}$ of isopropanol per $\mathrm{ml}$ of TRIzol Reagent ${ }^{\circledR}$ was then added and the solution was incubated for $10 \mathrm{~min}$ at room temperature, to precipitate the RNA. Centrifugation $\left(12,000 \mathrm{~g}\right.$ for $10 \mathrm{~min}$ at $\left.4{ }^{\circ} \mathrm{C}\right)$ was then used to the pellet RNA. The pellet was washed with $200 \mu \mathrm{L}$ of absolute ethanol and the RNA was then pellet again through centrifugation $\left(12,000 \mathrm{~g}\right.$ for $5 \mathrm{~min}$ at $\left.4{ }^{\circ} \mathrm{C}\right)$. The ethanol was then evaporated and the pellet was allowed to completely dry under a flow hood before adding $10 \mu \mathrm{L}$ of Diethyl pyrocarbonate (DEPC) water.

\subsubsection{Determination of total RNA and preparation of cDNA}

Determination of total RNA of each extraction was carried out with a Nanodrop using $1 \mu \mathrm{L}$ of RNA per sample (Thermo Scientific ${ }^{\mathrm{rm}}$ NanoDrop 2000). First strand cDNA synthesis was conducted using $0.2 \mu \mathrm{g}$ of RNA extract and was mixed with oligo-dT primers following the SuperScript ${ }^{\mathrm{TM}}$ III First-Strand Synthesis SuperMix protocol supplied by Invitrogen ${ }^{\mathrm{TM}}$.

\subsection{3. $q R T-P C R$ analysis}

cDNA amplification was performed using a LightCycler 480 Real Time PCR system (Biorad) using SYBR Green Power Master Mix (Invitrogen) with specific primer pairs (see supplemental material). Thermocycling was conducted using polymerase activation at $94^{\circ} \mathrm{C}$ for $2 \mathrm{~min}$ with an amplification and quantification cycle repeated for 50 cycles $\left(94^{\circ} \mathrm{C}\right.$ for $30 \mathrm{~s}, 58{ }^{\circ} \mathrm{C}$ for $30 \mathrm{~s}, 72^{\circ} \mathrm{C} 30 \mathrm{~s}$ ). The cq (Threshold cycle) values were recorded for analysis using actin as a housekeeper gene. Each gene was analyzed in triplicate.

\subsubsection{Statistical analysis and modelling}

Statistical Analysis was conducted using "R Studio 3.3.1" (R Studio Team, 2015). The measured values were compared among the different groups using nonparametric analysis through Kruskall-Wallis and Dunn's analysis ( $\mathrm{R}$ package dunn.test) with a $\mathrm{P}<0.05$ indicating statistical significance. P-values were then corrected using false discovery rate (fdr) using the R-package hmisc. To create an integrative analysis, partial least square discriminant analysis (PLS-DA) was used to determine if test conditions could be discriminated from the control (Bertrand et al., 2017; Cho et al., 2008). PLS-DA was selected as it has good performance when dealing with multi-collinear data with small samples and many variables (genes). ENMs and test condition (in vitro or in vivo) were analyzed separately to identify which genes were significantly impacted by the exposure conditions used. Variable Importance on Projection (VIP) was scored to identify which genes were most important in group discrimination (Jaumot et al., 2015). For each $\mathrm{CNF}$, both in vitro and in vivo exposures were plotted together. For each test condition, a correlation circle was plotted on the factorial plane combining the first two axes of the PLS-DA model. Vectors of the correlation circle represent the variables (genes) used to generate the model. Vectors describe the relationships between the genes and each of the axes.

To identify if production process influenced ecotoxicity, results were analyzed to determine if product features could be linked to gene expression. As the CNF products were similar in all aspects except for small differences due to the production process, the focus of the analysis was to determine if these differences could be linked to gene expression results. Two analyses of correlation were conducted to $i$ ) 

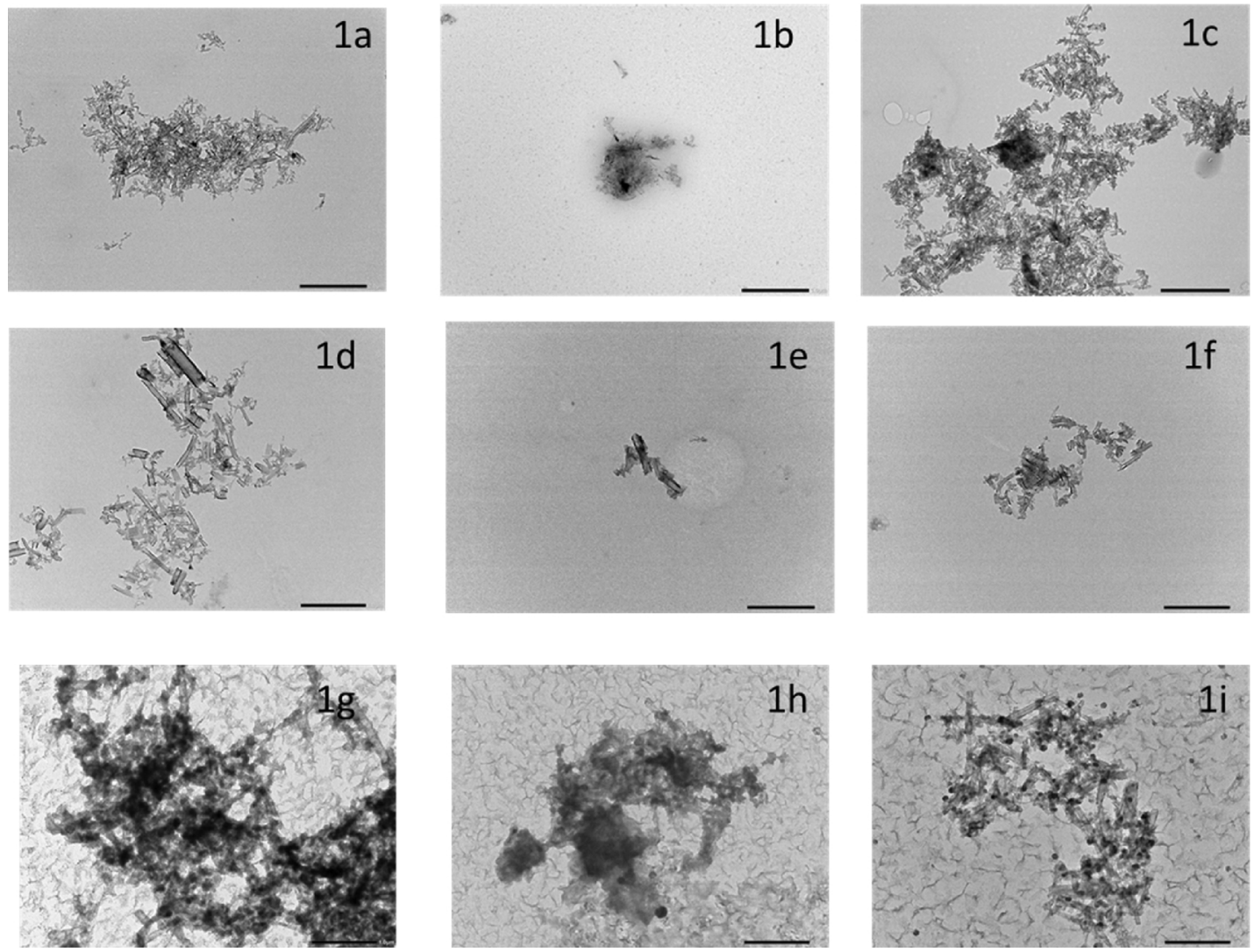

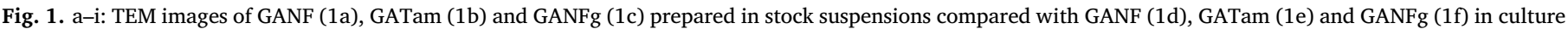
media and GANF ( $1 \mathrm{~g}$ ), GATam (1 h) and GANFg (1i) prepared in ASW. Black bars indicate $1 \mu \mathrm{m}$.

determine if gene expression could be correlated with the $\mathrm{I}_{\mathrm{D}} / \mathrm{I}_{\mathrm{G}}$-band ratio from Raman spectroscopy and ii) determine if there is a relationship between the reported purity of the CNFs. To achieve this, for each test condition (in vitro or in vivo) results were separated based on test concentration $\left(0.01,0.1\right.$ and $\left.1 \mathrm{mg} . \mathrm{L}^{-1}\right)$. Using these groups, Pearson's correlation coefficient was used to define their relationship between $I_{D} / I_{G}$ ratio and chemical purity with gene expressions. Each gene was analyzed at each test concentration to determine statistical significance using at $\mathrm{P}<0.05$.

\section{Results}

\subsection{Physicochemical characterization}

TEM results indicated that aggregation/agglomeration occurred in all media but no clear differences between suspensions could be identified (Fig. 1a-i). TEM results for ASW media were difficult to analyze due to deposition of salt during the grid preparation. Raman spectroscopy results indicated that the ratio between the Dband and Gband $\left(\mathrm{I}_{\mathrm{D}} / \mathrm{I}_{\mathrm{G}}\right)$ could be used to discriminate between the CNFs. GANF had a higher $\mathrm{I}_{\mathrm{D}} / \mathrm{I}_{\mathrm{G}}$-band ratio (1.26) than GATam (1.07) and GANFg(0.78) indicating that GANF has the highest number of structural defects and GANFg has the lowest number of structural defects (Fig. 2a-c).

All suspensions could be analyzed through DLS with results being considered good quality (Table 2). Stock suspensions for GANF (489.3 d-nm), GATam (414.3 d-nm) and GANFg (479.8 d-nm) were all comparable in the size of agglomerates. When prepared in culture media, GANF (260.1 d-nm), GATam (197.8 d-nm), and GANFg (244.1 d-nm) were still comparable in e but agglomerate sizes were notably smaller than the stock suspensions. This was also observed in ASW where GANF (186.7 d-nm), GATam (223 d-nm) and GANFg (217.4 d-nm) agglomerates were smaller in size when compared to the stock media but were similar in size to the measurements obtained in the cell culture media. The size of agglomerates after $24 \mathrm{~h}$ were similar to the start of the experiment for all test media.

The optical density measured in the stock suspension suggested that CNFs remaining in suspension were similar between GANF (11.5\%) and GATam (17.62\%) in the stock suspensions whereas GANFg was higher (47.72\%), suggesting more CNFs remained in suspension (Fig. 3). Optical density in cell culture media for GANF (47.88\%), GATam (86.34\%) and GANFg (89.80\%) was notably increased when compared to the stock suspension. For suspensions prepared in ASW, GANF (40.67\%) and GATam $(77.79 \%)$ where similar in optical density to the cell culture media. GANFg (40.67\%) had lower optical density in ASW.

\subsection{Gene expression analysis}

\subsubsection{In vivo}

Mussels exposed to the CNFs showed limited statistical significant between the control and the test concentrations for many of the genes suggesting little effects when exposed to the CNFs (Table 3). Histograms associated with the results can be found in the supplemental material.

3.2.1.1. Oxidative stress/detoxification. SOD mRNA levels were not significantly impacted. Catalase gene was significantly increased when exposed to GANF $\left(0.01\right.$ and $\left.1 \mathrm{mg} . \mathrm{L}^{-1}\right)$ and GATam (0.01 mg.. $\left.\mathrm{L}^{-1}\right)$. HSP70 was also not significantly increased when exposed to GANF $\left(0.01 \mathrm{mg} . \mathrm{L}^{-1}\right)$. GST was significantly increased by GATam (1 mg. $\left.\mathrm{L}^{-1}\right)$. Cytochrome P450 was significantly MT was significantly increased when exposed to GANFg $\left(0.1\right.$ and $\left.1 \mathrm{mg} . \mathrm{L}^{-1}\right)$.

3.2.1.2. Cytoskeleton, cell metabolism \& cell cycle control. B-tub was not significantly impacted. MRP was significantly decreased by GATam (0.01 and $\left.1 \mathrm{mg} . \mathrm{L}^{-1}\right)$ and GANFg $\left(1 \mathrm{mg} . \mathrm{L}^{-1}\right)$. Na/K ATPase was not 

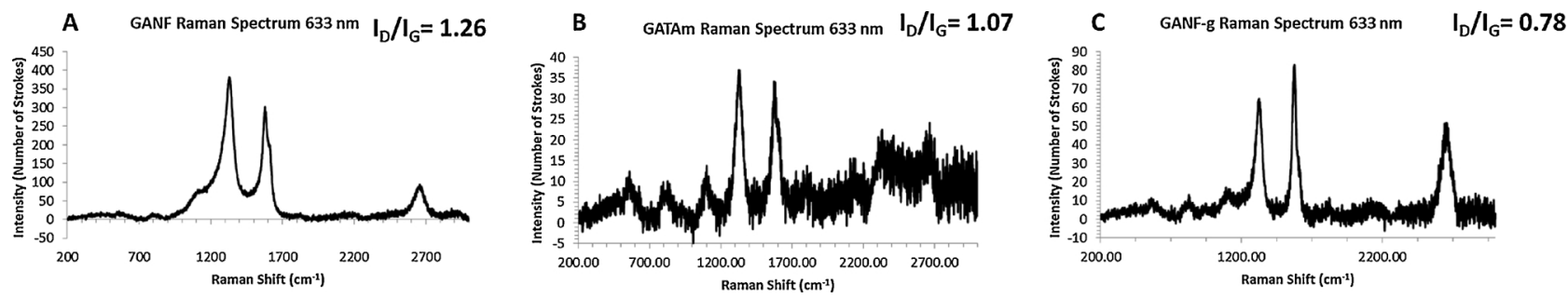

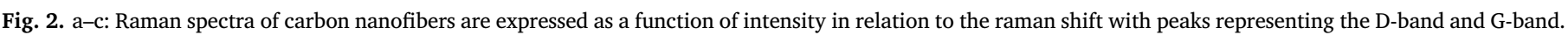
To measure the structural purity of GANF (A), GATam (B) and GANFg (C) the ratio of intensity between the D-band and G-band ( $\mathrm{I}_{\mathrm{D}} / \mathrm{I}_{\mathrm{G}}$ ) is used.

significantly impacted. P53 was significantly decreased by GANF $(0.01$ and $1 \mathrm{mg} . \mathrm{L}^{-1}$ ). Lysozyme gene expression was not significantly impacted.

\subsubsection{In vitro}

Mussels hemocytes exposed to the CNFs showed statistical significance with the in vitro exposure to all three CNFs with more significant effects occurring than with the in vivo exposure (Table 4). Histograms associated with the results can be found in the supplemental material.

3.2.2.1. Oxidative stress/detoxification. SOD mRNA levels were significantly decreased when mussels were exposed to GANF $\left(1 \mathrm{mg} . \mathrm{L}^{-1}\right)$, GATam $(0.01$ and $\left.0.1 \mathrm{mg} . \mathrm{L}^{-1}\right)$ and GANFg (0.01 and $\left.0.1 \mathrm{mg} . \mathrm{L}^{-1}\right)$. Catalase gene had no significant effects. HSP70 was also significantly increase for GANF ( 0.01 and $\left.1 \mathrm{mg} . \mathrm{L}^{-1}\right)$, GATAM $\left(0.1\right.$ and $\left.1 \mathrm{mg} . \mathrm{L}^{-1}\right)$ and GANFg $\left(0.01\right.$ and $\left.1 \mathrm{mg} . \mathrm{L}^{-1}\right)$. GST was significantly increased by GANF ( 0.1 and $1 \mathrm{mg} .-1 \mathrm{~L}$ ), GATam (0.1 mg. $\left.\mathrm{L}^{-1}\right)$ and GANFg ( 0.01 and $\left.1 \mathrm{mg} \cdot \mathrm{L}^{-1}\right)$. Cytochrome P450 was not statistically significant. MT was significantly increased when exposed to GANF ( 0.1 and $\left.1 \mathrm{mg} . \mathrm{L}^{-1}\right)$, GATAM ( $\left.1 \mathrm{mg} . \mathrm{L}^{-1}\right)$ and GANFg (0.01 and 1 mg.L $\left.{ }^{-1}\right)$.

3.2.2.2. Cytoskeleton, cell metabolism \&cell cycle control. B-tub was significantly decreased when exposed to GANF $\left(0.1\right.$ and $\left.1 \mathrm{mg} . \mathrm{L}^{-1}\right)$, GATam $\left(0.01\right.$ and $\left.0.1 \mathrm{mg} . \mathrm{L}^{-1}\right)$ and GANFg $\left(1 \mathrm{mg} . \mathrm{L}^{-1}\right)$. PgP was only significantly affected by GANF (1 mg.L $\left.{ }^{-1}\right)$. MRP was only affected by GATam $\left(0.01 \mathrm{mg} \cdot \mathrm{L}^{-1}\right)$. Na/K ATPase was only significantly affected by GANF (0.1 and $\left.1 \mathrm{mg} . \mathrm{L}^{-1}\right)$ and GATam $\left(0.1\right.$ and $\left.1 \mathrm{mg} . \mathrm{L}^{-1}\right)$. P53 was significantly increased by GATam $\left(0.01 \mathrm{mg} \cdot \mathrm{L}^{-1}\right)$. ATP synthase was significantly increased by GATam $\left(1 \mathrm{mg} . \mathrm{L}^{-1}\right)$ and significant decreased by GANFg $\left(0.01\right.$ and $\left.1 \mathrm{mg} . \mathrm{L}^{-1}\right)$. Lysozyme gene expression was not significantly impacted.

\subsection{PLS-DA analysis}

VIP values were identified for all 6 conditions and summarized in the Table 5. When analyzing the in vivo and in vitro exposure conditions most of the genes were identified as important in describing variation between test conditions $(>0.8)$. Of the genes used, consistently high VIP values were found with ATP synthase, P53, metallothionein, lysozyme, catalase and superoxide dismutase indicating these genes were essential in discriminating between test concentrations. The results of the model were then plotted on a factorial plane describing the relationship between genes (Fig. 4). This was then used to plot the test conditions of each CNF with their orientation dependent on which genes more effectively described the test condition (Fig. 5).

PLS-DA analysis for GANF in vivo showed that $0.01 \mathrm{mg} . \mathrm{L}^{-1}$ and $1 \mathrm{mg} . \mathrm{L}^{-1}$ test concentrations were be discriminated from the control and showed a high degree of separation (Fig. 5A). $0.1 \mathrm{mg} . \mathrm{L}^{-1}$ could be discriminated from the control but was similar in gene expression. When analyzing the PLS-DA model for GANF in vitro results showed that all three test concentrations could be discriminated from the control and showed a high degree of separation between concentrations. 0.01 and $0.1 \mathrm{mg} . \mathrm{L}^{-1}$ exposure times were similar in response. For both in vivo and in vitro results the $1 \mathrm{mg} . \mathrm{L}^{-1}$ test concentration was clearly separated.

The PLS-DA model for GATam in vivo results also showed discrimination from the control at $0.01,0.1 \mathrm{mg} . \mathrm{L}^{-1}$ and at $1 \mathrm{mg} . \mathrm{L}^{-1}$ (Fig. 5B). This pattern was observed as well for the in vitro test condition but little similarities were observed between the two test conditions.

The PLS-DA model GANFg in vivo had a clear separation of the test concentrations from the control (Fig. 5C). GANFg in vitro showed clear separation from the control for all three test concentrations and $0.01 \mathrm{mg} . \mathrm{L}^{-1}$ and $1 \mathrm{mg} . \mathrm{L}^{-1}$ exposure conditions were similar in response.

\subsection{Correlating CNF form with gene expression}

To determine if relationships between gene expression and differences in the CNF production process could be established Pearson's correlation coefficient and CNF structural purity (as measured through Raman spectrometry) was used. Positive correlations would indicate that as the $\mathrm{I}_{\mathrm{D}} / \mathrm{I}_{\mathrm{G}}$-band ratio increases, gene expression increases where

Table 2

DLS results measured in stock suspension, cell culture media and ASW at the start of the experiment and at the end. Zeta potential was only able to measured in the stock suspensions due to the high ionic strengths in the test media.

\begin{tabular}{|c|c|c|c|c|c|c|c|c|c|}
\hline & \multicolumn{3}{|l|}{ GANF } & \multicolumn{3}{|l|}{ GATam } & \multicolumn{3}{|l|}{ GANFg } \\
\hline & Z-average (d-nm) & PdI & Zeta Potential (mV) & Z-average (d-nm) & PdI & Zeta Potential (mV) & Z-average (d-nm) & PdI & Zeta Potential (mV) \\
\hline Stock Suspension & 489.3 & 0.128 & -10.1 & 414.3 & 0.231 & -13.8 & 479.8 & 0.178 & -15.6 \\
\hline M. edulis Culture Media & 260.1 & 0.359 & - & 197.8 & 0.272 & - & 244.1 & 0.325 & - \\
\hline \multirow{3}{*}{$\begin{array}{l}\text { Artificial Sea Water } \\
\text { End of Experiment }\end{array}$} & 186.7 & 0.306 & - & 223 & 0.311 & - & 217.4 & 0.307 & - \\
\hline & GANF & & & GATam & & & GANFg & & \\
\hline & Z-average (d-nm) & PdI & Zeta Potential (mV) & Z-average (d-nm) & PdI & Zeta Potential (mV) & Z-average (d-nm) & PdI & Zeta Potential (mV) \\
\hline Stock Suspension & 527.5 & 0.123 & -15.9 & 389.4 & 0.164 & -13 & 441.2 & 0.285 & -14.8 \\
\hline M. edulis Culture Media & 221.4 & 0.32 & - & 164.3 & 0.23 & - & 237.2 & 0.226 & - \\
\hline Artificial Sea Water & 278.3 & 0.418 & - & 220.5 & 0.348 & - & 348.1 & 0.77 & - \\
\hline
\end{tabular}




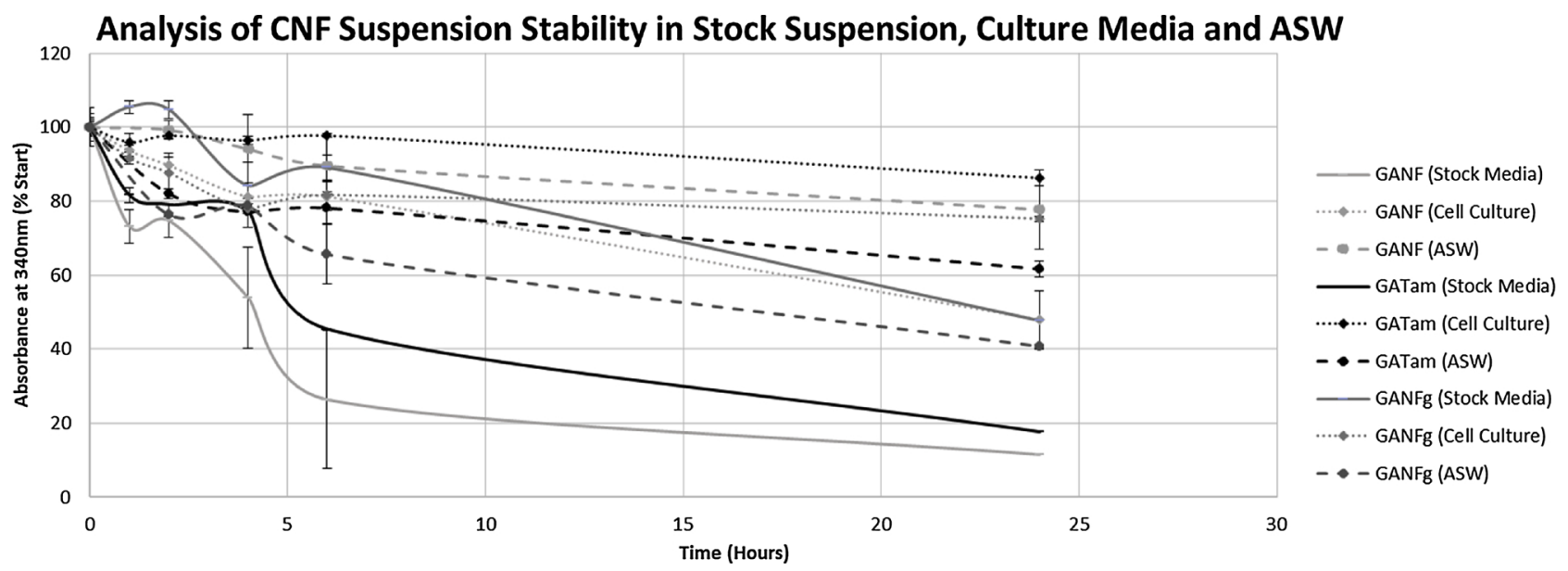

Fig. 3. Optical density $(340 \mathrm{~nm})$ as an approximation of suspension stability of the CNFs in the stock suspensions, cell culture media and in ASW over 24 h.

as a negative correlation would result in an inverse interpretation. Significant positive correlations in the relationship between gene expression and CNF purity would imply that as purity increases, gene expression increases. A negative correlation would suggest that as purity decreases, gene expression increases.

When test concentrations were controlled for strong correlations between gene expression and $\mathrm{I}_{\mathrm{D}} / \mathrm{I}_{\mathrm{G}}$-band ratio could be identified (Table 6). For the in vivo exposure there were clear differences with test concentration and relationship $\mathrm{I}_{\mathrm{D}} / \mathrm{I}_{\mathrm{G}}$-band ratio. At a concentration of $0.01 \mathrm{mg} . \mathrm{L}^{-1}$ HSP70, GST, SOD, ATP synthase and B-tubulin gene expressions had strong positive correlations with the $\mathrm{I}_{\mathrm{D}} / \mathrm{I}_{\mathrm{G}}$-band ratio where at a dose of $0.1 \mathrm{mg} . \mathrm{L}^{-1}$ only MRP gene had a significant correlation. For mussels exposed to $1 \mathrm{mg} . \mathrm{L}^{-1}$, metallothionein, lysozyme, PgP, ATP synthase, P53 and MRP gene expression levels had all positive correlations. However, mussels exposed in vitro to $0.01 \mathrm{mg} . \mathrm{L}^{-1}$, showed that HSP70, GST, metallothionein and ATP synthase mRNA levels had significant negative correlations with the $\mathrm{I}_{\mathrm{D}} / \mathrm{I}_{\mathrm{G}}$-band ratio where $\mathrm{Na} / \mathrm{K}$ ATPase and MRP genes had significant positive correlations. At a concentration of $0.1 \mathrm{mg} . \mathrm{L}^{-1}$, SOD, lysozyme, PgP and cytochromeP450 gene expression levels had negative correlations and GST, Na/K ATPase and P53 genes had positive correlations. At a concentration of $1 \mathrm{mg} . \mathrm{L}^{-1}$, SOD, lysozyme, cytochromeP450 and ATP synthase mRNA levels had strong positive correlations.

When determining the relationship between gene expression and CNF chemical purity (as reported in Table 1), there were some significant relationships were identified but there were less correlations than when comparing gene expression to the $\mathrm{I}_{\mathrm{D}} / \mathrm{I}_{\mathrm{G}}$ band ratio (Table 7 ).
When looking at the in vivo exposure condition, $\beta$-tubulin, $\mathrm{Na} / \mathrm{K}$ ATPase and P53 genes had significant negative correlations with purity of the $\mathrm{CNF}$ at $0.01 \mathrm{mg} . \mathrm{L}^{-1}$. At $0.1 \mathrm{mg} . \mathrm{L}^{-1}$ exposure condition, HSP70, GST, SOD, $\beta$-tubulin and MRP mRNA expressions depicted significant negative correlations with purity whereas catalase gene had a significant positive relationship. At $1 \mathrm{mg} . \mathrm{L}^{-1}$, only MRP showed a significant negative correlation to the purity. For the in vitro exposure condition, $\mathrm{PgP}$, cytochromeP450 and $\mathrm{Na} / \mathrm{K}$ ATPase mRNA levels had negative correlations whereas GST and P53 genes had positive correlations. At $1 \mathrm{mg} . \mathrm{L}^{-1}$, HSP70 and $\mathrm{Na} / \mathrm{K}$ ATPase expressions had significant negative relationships whereas GST and PgP mRNA levels had significant positive relationships with purity of CNF.

\section{Discussion}

The aim of the study was to investigate whether or not differences in the production process of CNFs would alter gene expression profiles as well as to establish an in vitro/in vivo comparison. In this sense, the first objective was to establish if the three CNFs have similar physicochemical and to determine differences between in vitro and in vivo stability and hydrodynamic diameters.

\subsection{Physico-chemical characterization}

To maintain a relevant comparison between the $3 \mathrm{CNFs}$, the physico-chemical properties of the CNFs in suspensions need to be accounted for. In this sense, DLS is a commonly used technique for

Table 3

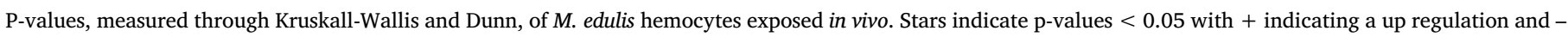
indicating down regulation.

\begin{tabular}{|c|c|c|c|c|c|c|c|c|c|}
\hline & GANF & & & GATam & & & GANFg & & \\
\hline & $0.01 \mathrm{mg} / \mathrm{L}$ & $0.1 \mathrm{mg} / \mathrm{L}$ & $1 \mathrm{mg} / \mathrm{L}$ & $0.01 \mathrm{mg} / \mathrm{L}$ & $0.1 \mathrm{mg} / \mathrm{L}$ & $1 \mathrm{mg} / \mathrm{L}$ & $0.01 \mathrm{mg} / \mathrm{L}$ & $0.1 \mathrm{mg} / \mathrm{L}$ & $1 \mathrm{mg} / \mathrm{L}$ \\
\hline Cat & +0.01 & -0.09 & +0.05 & +0.04 & +0.37 & +0.5 & +0.15 & -0.15 & +0.15 \\
\hline HSP70 & -0.13 & +0.13 & +0.5 & +0.06 & -0.15 & +0.15 & +0.15 & -0.15 & -0.06 \\
\hline GST & +0.29 & +0.29 & +0.29 & +0.19 & +0.46 & +0.03 & +0.06 & +0.13 & +0.13 \\
\hline SOD & +0.11 & -0.11 & -0.45 & +0.13 & -0.15 & +0.13 & +0.33 & -0.23 & -0.08 \\
\hline MT & -0.37 & -0.37 & -0.06 & +0.15 & +0.06 & -0.15 & +0.01 & +0.03 & +0.1541 \\
\hline P53 & +0.15 & +0.15 & +0.06 & +0.15 & +0.06 & -0.15 & +0.01 & +0.15 & +0.01 \\
\hline $\mathrm{PgP}$ & +0.01 & +0.33 & +0.16 & -0.21 & +0.05 & +0.19 & +0.11 & +0.41 & +0.01 \\
\hline CP450 & +0.05 & -0.5 & -0.5 & -0.37 & +0.32 & +0.32 & +0.29 & +0.29 & +0.06 \\
\hline Asyn & -0.03 & -0.15 & -0.01 & -0.15 & +0.06 & +0.15 & -0.01 & -0.07 & -0.07 \\
\hline Lys & +0.33 & -0.33 & -0.33 & -0.15 & +0.06 & +0.15 & +0.16 & -0.29 & $-0.04 *$ \\
\hline Na.K & +0.08 & +0.25 & +0.23 & +0.15 & -0.06 & +0.15 & +0.15 & -0.15 & -0.13 \\
\hline MRP & -0.43 & -0.45 & -0.43 & +0.04 & +0.41 & +0.04 & -0.41 & -0.32 & -0.03 \\
\hline Btub & -0.15 & +0.06 & +0.02 & +0.15 & -0.06 & +0.15 & +0.15 & -0.15 & -0.06 \\
\hline
\end{tabular}


Table 4

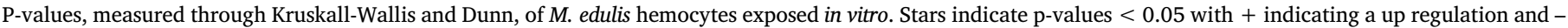
indicating down regulation.

Statistical Significant in gene expression: in vitro

\begin{tabular}{|c|c|c|c|c|c|c|c|c|c|}
\hline & \multicolumn{3}{|l|}{ GANF } & \multicolumn{3}{|l|}{ GATam } & \multicolumn{3}{|l|}{ GANFg } \\
\hline & $0.01 \mathrm{mg} / \mathrm{L}$ & $0.1 \mathrm{mg} / \mathrm{L}$ & $1 \mathrm{mg} / \mathrm{L}$ & $0.01 \mathrm{mg} / \mathrm{L}$ & $0.1 \mathrm{mg} / \mathrm{L}$ & $1 \mathrm{mg} / \mathrm{L}$ & $0.01 \mathrm{mg} / \mathrm{L}$ & $0.1 \mathrm{mg} / \mathrm{L}$ & $1 \mathrm{mg} / \mathrm{L}$ \\
\hline Cat & +0.37 & -0.37 & -0.37 & -0.27 & +0.323 & +0.17 & +0.21 & -0.21 & +0.21 \\
\hline HSP70 & $-0.03^{*}$ & -0.15 & $-0.03^{*}$ & -0.15 & $-0.03^{*}$ & $-0.01 *$ & $-0.01^{*}$ & -0.13 & $-0.01 *$ \\
\hline GST & -0.15 & $-0.03^{*}$ & $-0.01^{*}$ & -0.15 & $0.01 *$ & -0.10 & $-0.01 *$ & -0.15 & $-0.01 *$ \\
\hline SOD & -0.09 & -0.07 & $-0.01^{*}$ & $-0.01^{*}$ & $-0.02^{*}$ & -0.15 & $-0.01^{*}$ & $-0.01^{*}$ & -0.15 \\
\hline MT & -0.15 & $-0.03^{*}$ & $-0.01^{*}$ & -0.06 & -0.06 & $-0.01^{*}$ & $-0.04^{*}$ & -0.13 & $-0.01 *$ \\
\hline Lys & +0.06 & +0.15 & +0.15 & +0.16 & +0.29 & $+0.04 \%$ & +0.15 & -0.15 & +0.08 \\
\hline $\mathrm{PgP}$ & +0.33 & +0.33 & $+0.03^{*}$ & -0.21 & -0.08 & +0.19 & +0.06 & -0.15 & +0.15 \\
\hline CP450 & -0.33 & +0.16 & -0.16 & -0.11 & -0.11 & -0.25 & +0.29 & -0.19 & +0.19 \\
\hline Asyn & +0.13 & +0.13 & -0.13 & -0.09 & -0.21 & $-0.01 *$ & $-0.01 *$ & -0.15 & $-0.03^{*}$ \\
\hline Btub & -0.11 & $-0.05^{*}$ & $-0.01^{*}$ & $-0.01 *$ & $-0.02^{*}$ & -0.15 & -0.07 & -0.07 & $-0.01 *$ \\
\hline Na.K & -0.15 & $-0.03^{*}$ & $-0.01^{*}$ & +0.15 & $-0.02^{*}$ & $-0.01 *$ & -0.15 & -0.15 & -0.08 \\
\hline P53 & +0.13 & +0.13 & -0.15 & +0.01 & +0.07 & +0.37 & +0.06 & +0.15 & +0.15 \\
\hline MRP & +0.33 & -0.16 & -0.16 & +0.33 & +0.16 & -0.16 & $-0.04 *$ & +0.16 & -0.29 \\
\hline
\end{tabular}

Table 5

VIP values of genes expression for each exposure condition to CNFs. VIP values below 0.8 were removed from the analysis.

\begin{tabular}{lllllll}
\hline \multicolumn{2}{l}{ VIP Values } & \multicolumn{7}{l}{$l$} \\
\hline & $\begin{array}{l}\text { GAtam (in } \\
\text { vivo) }\end{array}$ & $\begin{array}{l}\text { GAtam (in } \\
\text { vitro) }\end{array}$ & $\begin{array}{l}\text { GANFg (in } \\
\text { vivo) }\end{array}$ & $\begin{array}{l}\text { GANFg (in } \\
\text { vitro) }\end{array}$ & $\begin{array}{l}\text { GANF } \\
\text { (in vitro) }\end{array}$ & $\begin{array}{l}\text { GANF } \\
\text { (in vivo) }\end{array}$ \\
\hline Asyn & 1.06 & 0.97 & 1.34 & 0.94 & 0.95 & 1.43 \\
P53 & 1.05 & 1.13 & 1.34 & 1.14 & 0.97 & 1.3 \\
MT & 1.09 & 1 & 1.4 & 1.02 & 0.89 & 1.28 \\
PgP & 1.16 & 1.01 & 0.93 & 1.02 & 0.67 & 1.06 \\
HSP70 & 0.94 & 1.01 & 1.08 & 0.92 & 0.94 & 1.03 \\
B.Tub & 0.92 & 1.17 & 0.93 & 0.98 & 0.96 & 1.03 \\
SOD & 0.82 & 1.16 & 0.84 & 1.49 & 0.97 & 0.98 \\
Na.K & 0.97 & 1.01 & 0.84 & 0.51 & 0.87 & 0.98 \\
Cat & 1.39 & 0.72 & 0.33 & 0.82 & 0.28 & 0.92 \\
CP450 & 0.78 & 0.88 & 0.62 & 1.16 & 0.61 & 0.9 \\
Lys & 1.3 & 0.96 & 0.82 & 1.06 & 1.8 & 0.6 \\
GST & 0.65 & 1.07 & 0.85 & 1.04 & 1.21 & 0.53 \\
MRP & 0.6 & 0.8 & 1.04 & 0.12 & 0.95 & 0.4 \\
\hline
\end{tabular}

measuring ENMs in suspension but it is limited in the sense that it assumes a spherical shape for the particles. In the context of CNFs this does not hold true for the single fibers, but agglomerates can be approximated as ovoid and the size of the particles can be approximated (Reinert et al., 2015).The DLS results suggest that particle sizes are comparable between CNFs as well as between in vitro and in vivo assays. In addition to this, the optical density results suggest that the test suspensions are somewhat stable with slight differences between in vitro and in vivo test media for GATam and GANF. As a result, the CNFs used in the study can be considered to have similar physico-chemical properties between the two testing strategies, facilitating an in vitro/in vivo comparison. It is however important note that differences between the media may lead to differences in sedimentation and effectively change the dosimetry.

Another interesting observation is that the CNFs displayed poor stability in ultra-pure water whereas in both culture media and ASW the stability was improved. One potential explanation for this observation is that the ionic strength of these suspensions decreased the surface potential of the CNFs, reducing rate at which particles interact with other another (Pavlin and Bregar, 2012). This is interesting as it would imply that the behavior of the CNFs in the ocean will be different than the behavior in fresh water ecosystem, which can lead to distinct differences in toxicity profiles.

Of the methods used to characterize the CNFs in the present study, only Raman spectroscopy demonstrated clear differences between the CNFs. The comparison of the Raman spectra of the 3 samples illustrates the influence of the annealing treatment with a clear improvement of the $\mathrm{I}_{\mathrm{D}} / \mathrm{I}_{\mathrm{G}}$ intensity ratio, decreasing from 1.3 (Fig. 2(a)) to 0.8 (Fig. 2(c)) and evidencing a significant improvement of the structure of the carbon network, also visible with the increased intensity of the $2 \mathrm{D}$ band (2650 cm-1). Sample GATam (Fig. 2(b)) lies in between with an intermediate value of the $\mathrm{I}_{\mathrm{D}} / \mathrm{I}_{\mathrm{G}}$ intensity ratio of 1.1 but a noisier spectrum, although all data were acquired exactly in the same experimental conditions. All 3 samples exhibited some fluorescence leading to an important background signal. For this reason, irradiation of the samples started $30 \mathrm{~s}$ before acquisition to limit this phenomenon. It is important to note that Raman spectroscopy does not allow a direct measurement of the chemical purity of the samples but more of the level of structural defects (Ivanova et al., 2012). In the context of SbD and the case study this is important because the structural quality of the CNFs may impact the performance of the products and GATam may be a more desirable product than GANF as a result. In the context of ecotoxicological hazards structural defects can lead to the functionalization of CNFs, providing favorable binding sites for ions or molecules, which can lead to differences in hazard profiles.

\subsection{Gene expression}

The endpoints used in the present study provides broad spectrum response analysis of hemocyte gene expression to CNF exposure, which allows for characterization of mechanisms of action. To the authors' best knowledge, this is the first time that carbon nanofibers have been investigated for ecotoxicological effects on mussels. As a result, there are limited examples that could be considered a suitable comparison. Of the information available mussel hemocytes, exposed in vitro and in vivo for $24 \mathrm{~h}$, have been shown to display sublethal responses to carbon black and fullerene $\left(0.01-1 \mathrm{mg} . \mathrm{L}^{-1}\right)$ with little to no effects when exposed to a carbon nanotube (0.01-1 mg. $\mathrm{L}^{-1}$ ) (Canesi et al., 2010, 2008b; Moore et al., 2009). Previous studies in human toxicology have shown induction of oxidative stress and inflammation when cells, IL-8, A549 and HaCaT, were exposed to multi-walled carbon nanotubes at $1 \mathrm{mg} / \mathrm{L}$ and $25 \mathrm{mg} . \mathrm{L}^{-1}$ for $24 \mathrm{~h}$ (Vitkina et al., 2016; Ye et al., 2009). When analyzing the in vivo responses, the gene expression had little significant effects (which may be attributed to the small sample sizes) with all three CNFs and little clear pattern is evident with the CNFs. There is a however a notable trend for GATam to have higher fold expressions which could suggest more adverse effects may occur with this CNF.

When looking at the in vitro exposure however, hemocytes showed more significant effects when compared to the in vivo exposure for all CNFs with many of the gene response associated with oxidative and xenobiotic stress. This can be attributed to the simpler exposure 

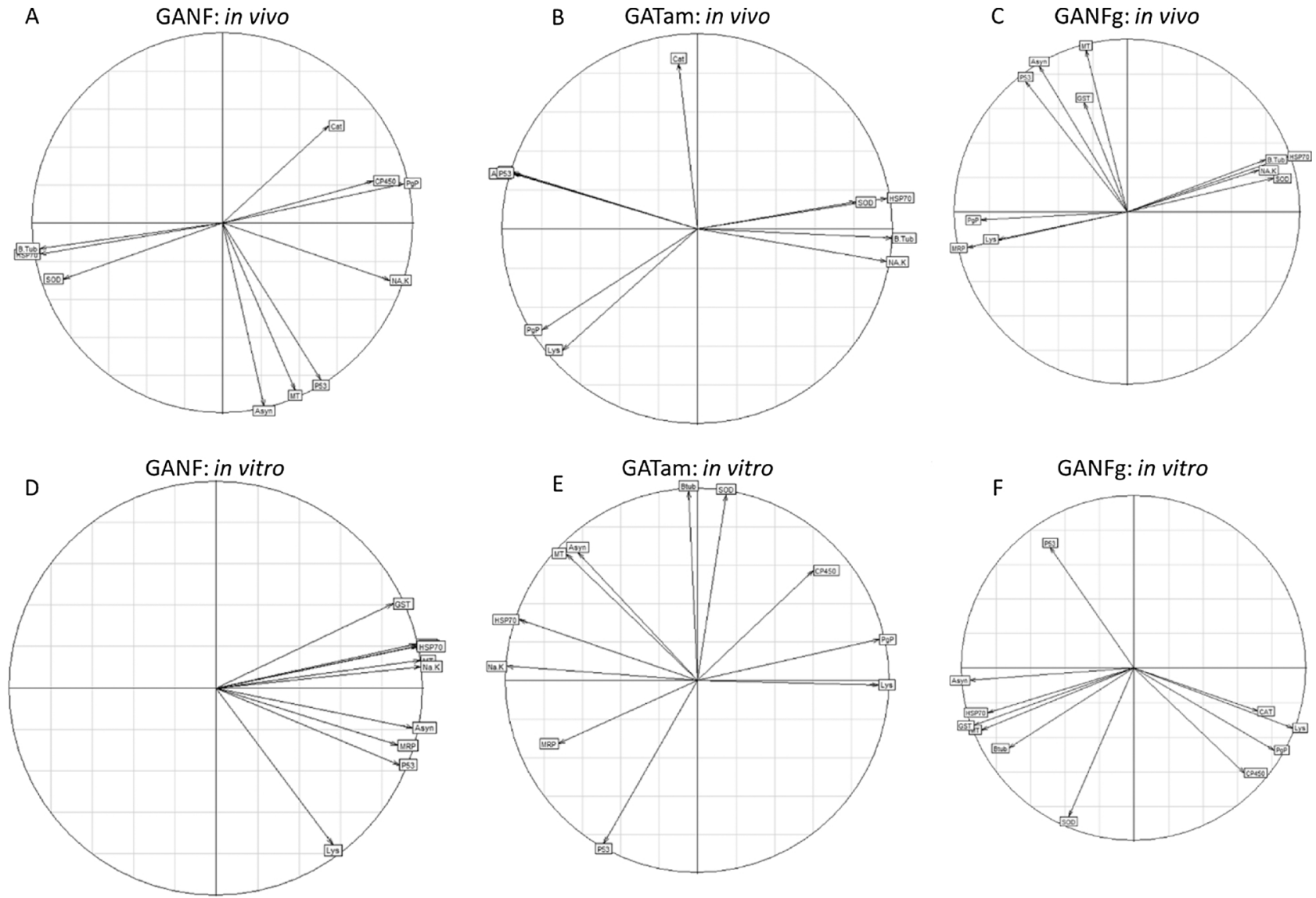

Fig. 4. PLS-DA correlation for all test conditions in vivo for GANF (A), GATam (B) and GANFg (C) as well as in vitro for GANF (D), GATam (E) and GANFg (F) plotted on a factorial plane. Orientation of the vectors describes how strongly each gene describes the axes as well as the relationship between genes.

scenario for the in vitro exposure as the cells are directly exposed to the CNFs. When looking at the results for approximated stability, GANF showed the least stability of the three CNFs in culture media. This observation could suggest that due to the a sedimentation effect the effective dosage for GANF is higher than the other two CNFs (Deloid et al., 2017; Hinderliter et al., 2010). This could also suggest that these CNFs are aggregating at the bottom of the well and not interacting with the cells, which can complicate the comparison between the three CNFs. Looking at the gene expression holistically more significant effects occur with GANFg at $0.01 \mathrm{mg} . \mathrm{L}^{-1}$ which could suggest this product is more hazardous. The results of the in vitro approach may suggest that all three CNFs could potentially cause oxidative and xenobiotic stress, which is not in agreement with the in vivo approach. It is also important to note that the cell culture is a complex media consisting of a mixture of proteins, which can lead to protein corona that does not occur naturally. As a result, further analysis of dosimetry may be necessary when applying an in vitro approach for SbD in order to demonstrate it is an accurate predictor of in vivo effects.

\subsection{PLS-DA analysis}

The integrative analysis through PLS-DA showed some unexpected results in that almost all of the genes were important in the discrimination between test concentrations for all the CNFs and for both in vivo and in vitro test conditions, highlighting its sensitivity in identifying sublethal effects. Of these genes however, ATP synthase, P53,

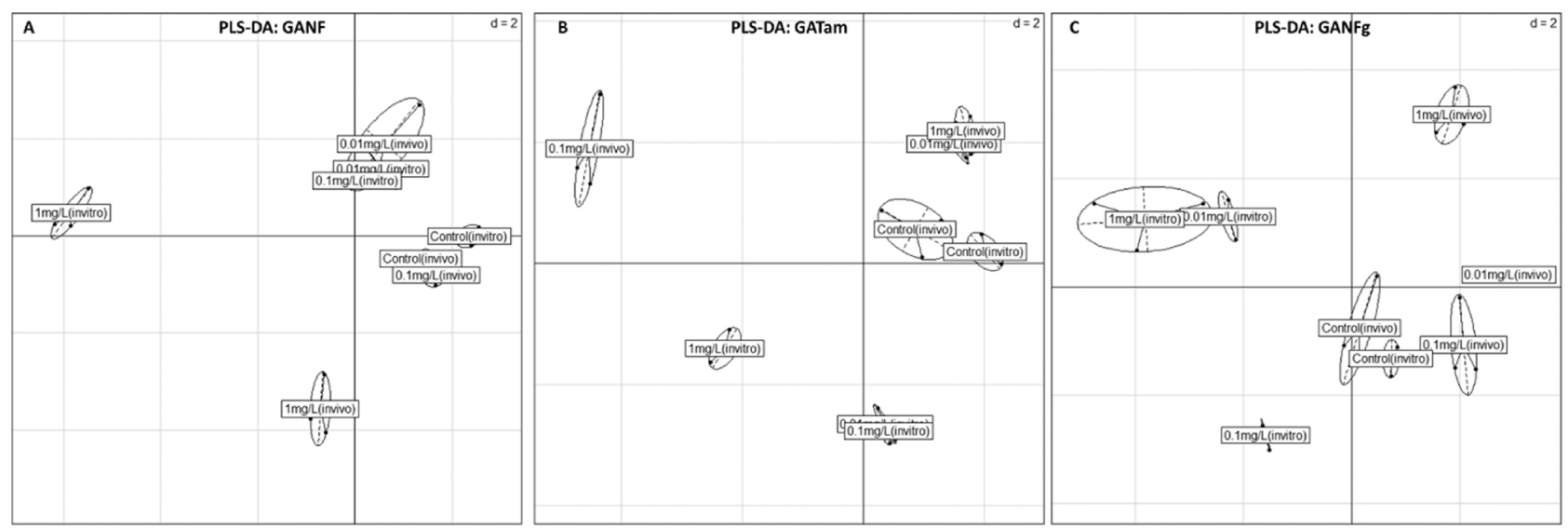

Fig. 5. PLS-DA analysis of $M$. edulis hemocytes exposed in vitro and in vivo to GANF (A), GAtam (B) and GANFg (C) at $0.01,0.1$ and $1 \mathrm{mg} . \mathrm{L}^{-1}$. 
Table 6

Table showing the correlation between the D/G-band ratio, measured through Raman spectroscopy, and gene expression. *Indicates statistical significant $(\mathrm{P}<0.05)$ with + indicating a positive relationship with purity and - indicating a negative relationship with purity.

\begin{tabular}{|c|c|c|c|c|c|c|}
\hline & \multicolumn{2}{|c|}{$0.01 \mathrm{mg} / \mathrm{L}$} & \multicolumn{2}{|l|}{$0.1 \mathrm{mg} / \mathrm{L}$} & \multicolumn{2}{|l|}{$1 \mathrm{mg} / \mathrm{L}$} \\
\hline & in vitro & in vivo & in vitro & in vivo & in vitro & in vivo \\
\hline Cat & +0.52 & +0.06 & -0.16 & -0.44 & +0.56 & +0.51 \\
\hline HSP70 & $-0.93^{*}$ & $+0.84 *$ & -0.3 & +0.26 & +0.32 & +0.23 \\
\hline GST & $-0.91 *$ & $+0.69^{*}$ & $+0.7^{*}$ & +0.59 & -0.22 & +0.49 \\
\hline SOD & -0.55 & $+0.85^{*}$ & $-0.74^{*}$ & +0.55 & $+0.79^{*}$ & +0.57 \\
\hline MT & $-0.88^{*}$ & +0.54 & -0.07 & +0.42 & +0.48 & $+0.77 *$ \\
\hline Lys & -0.07 & +0.30 & $-0.92^{*}$ & +0.12 & $+0.83^{*}$ & $+0.86^{*}$ \\
\hline $\mathrm{PgP}$ & +0.69 & -0.36 & $-0.93^{*}$ & +0.32 & -0.29 & $+0.94 *$ \\
\hline CP450 & +0.46 & -0.39 & $-0.94 *$ & +0.3 & $+0.84^{*}$ & +0.66 \\
\hline Asyn & $-0.97^{*}$ & $+0.87^{*}$ & -0.29 & +0.29 & $+0.78^{*}$ & $+0.89 *$ \\
\hline Btub & -0.62 & $+1 *$ & -0.65 & +0.21 & -0.18 & +0.51 \\
\hline Nak & $+0.94 *$ & +0.53 & $+0.9^{*}$ & +0.19 & +0.32 & +0.39 \\
\hline P53 & -0.34 & +0.15 & $+0.96^{*}$ & +0.26 & +0.34 & $+0.89 *$ \\
\hline MRP & $+0.75^{*}$ & +0.5 & +0.06 & $+0.82^{*}$ & +0.45 & $+0.97^{*}$ \\
\hline
\end{tabular}

Table 7

Table showing the correlation between carbon nanofiber purity and gene expression. *indicate statistical significant $(\mathrm{P}<0.05)$ with + indicating a positive relationship with purity and - indicating a negative relationship with purity.

Correlation with Reported CNF Purity

\begin{tabular}{|c|c|c|c|c|c|c|}
\hline & \multicolumn{2}{|c|}{$0.01 \mathrm{mg} / \mathrm{L}$} & \multicolumn{2}{|l|}{$0.1 \mathrm{mg} / \mathrm{L}$} & \multicolumn{2}{|l|}{$1 \mathrm{mg} / \mathrm{L}$} \\
\hline & in vitro & in vivo & in vitro & in vivo & in vitro & in vivo \\
\hline Cat & -0.66 & +0.28 & +0.47 & $+0.75^{*}$ & -0.2 & -0.58 \\
\hline HSP70 & +0.57 & -0.33 & -0.35 & $-0.79 *$ & $-0.76^{*}$ & +0.39 \\
\hline GST & $+0.74 *$ & -0.23 & $-0.92 *$ & -0.65 & $+0.70^{*}$ & +0.13 \\
\hline SOD & -0.02 & -0.35 & +0.23 & $-0.92^{*}$ & -0.21 & +0.02 \\
\hline MT & +0.67 & -0.34 & -0.12 & +0.22 & +0.1 & -0.26 \\
\hline Lys & -0.52 & -0.37 & +0.64 & +0.5 & -0.33 & -0.38 \\
\hline $\mathrm{PgP}$ & $-0.89^{*}$ & -0.27 & +0.58 & +0.32 & $+0.8^{*}$ & -0.54 \\
\hline CP450 & $-0.73^{*}$ & -0.03 & $+0.68^{*}$ & +0.16 & -0.54 & -0.43 \\
\hline Asyn & +0.64 & -0.39 & -0.30 & +0.36 & -0.3 & -0.43 \\
\hline Btub & +0.03 & $-0.83^{*}$ & +0.06 & $-0.76^{*}$ & +0.64 & +0.11 \\
\hline Nak & $-0.85^{*}$ & $-0.93 *$ & $-0.84^{*}$ & $-0.74 *$ & $-0.69^{*}$ & +0.23 \\
\hline P53 & $+0.82^{*}$ & $-0.69 *$ & -0.64 & +0.39 & +0.05 & -0.5 \\
\hline MRP & $-0.84 *$ & -0.11 & -0.57 & $-0.77 *$ & +0.04 & -0.78 \\
\hline
\end{tabular}

metallothionein, $\mathrm{PgP}$ and HSP70 were identified as the most important discriminators for almost all test conditions. This suggests that exposure to the CNFs is influencing a wide array of cellular functions (oxidative stress, detoxification, cytoskeleton, cellular metabolism and cell cycle control) which can alter cell functioning and potentially cascade into higher levels of biological organization. When comparing the VIP values in vivo to in vitro it became apparent that in general there were some similarities in the values between the two testing conditions. However, when analyzing the correlation circles the relationship between genes was not consistent between the in vitro and in vivo exposures. The in vivo/in vitro relationship is a challenge to many investigators as gene responses are often not consistent between the two testing strategies (Heise et al., 2012).

\subsection{Correlation CNF properties to gene expression}

In the context of applying ecotoxicology to a SbD for MNMs, there needs to be an identification of what features of MNMs cause toxicity. The CNFs used in the present study provide an ideal case study for the application of SbD as the products are very similar which allow for an analysis on how the differences in production influence ecotoxicity. In this sense, structural purity, measured through the $\mathrm{I}_{\mathrm{D}} / \mathrm{I}_{\mathrm{G}}$-band ratio, and overall purity were identified as potential discriminators between the CNFs. Of these two measurements, the relationship between the $\mathrm{I}_{\mathrm{D}} / \mathrm{I}_{\mathrm{G}^{-}}$ band ratio proved to be more strongly correlated with gene expression than chemical purity of CNF. In vivo, all the genes showed a positive correlation with the $\mathrm{I}_{\mathrm{D}} / \mathrm{I}_{\mathrm{G}}$-band ratio indicating that gene expression increased with structural impurities. With the in vitro results however, the inverse is observed in the fact that gene expression was more strongly correlated with a decrease in the $\mathrm{I}_{\mathrm{D}} / \mathrm{I}_{\mathrm{G}}$-band ratio. A previous study investigating the physicochemical relationship between toxicity and MWNCT was able to demonstrate that the presence of proteins profoundly affects their behavior in media and could alter their toxicity as a result, which may explain the difference in interpretation (Allegri et al., 2016). The relationship between test media properties and CNFs behavior requires further investigation, in particular the role of a protein corona in gene expression. This does however provide insight that could be useful in linking ecotoxicity results in a way that can promote SbD strategies.

\section{Conclusion}

Transcriptomic is a promising emerging tool to implement ecotoxicology into a SbD approach for MNMs. The results in the present study demonstrate a way in which gene expression can be used to provide information to improve the safety of MNM products. In the context of the current study the in vitro and in vivo tests were not consistent in their interpretation of which CNF was "least safe", suggesting that in vitro and in vivo strategies need to be investigated in parallel to verify that an in vitro approach using $M$. edulis hemocytes is a suitable alternative testing strategy. It is however important to note that while in vitro/in vivo extrapolation remains a challenge requiring additional research, the application of ecotoxicology in SbD may require the use of in vitro testing to adequately screen products produced by industry in a cost effective and timely manner.

"The sole responsibility of this publication lies with the author. The European Union is not responsible for any use that may be made of the information contained therein."

\section{Acknowledgements}

The research contained within this publication was funded by the European Union's Horizon 2020 research and innovation program NANoREG2 under grant agreement 646221.

\section{Appendix A. Supplementary data}

Supplementary material related to this article can be found, in the online version, at doi:https://doi.org/10.1016/j.aquatox.2018.11.020.

\section{References}

Allegri, M., Perivoliotis, D.K., Bianchi, M.G., Chiu, M., Pagliaro, A., Koklioti, M.A., Trompeta, A.F.A., Bergamaschi, E., Bussolati, O., Charitidis, C.A., 2016. Toxicity determinants of multi-walled carbon nanotubes: the relationship between functionalization and agglomeration. Toxicol. Rep. 3, 230-243. https://doi.org/10.1016/j. toxrep.2016.01.011.

Barrick, A., Châtel, A., Bruneau, M., Mouneyrac, C., 2017. The role of high-throughput screening in ecotoxicology and engineered nanomaterials. Environ. Toxicol. Chem. 9999, 1-11. https://doi.org/10.1002/etc.3811.

Barrick, A., Guillet, C., Mouneyrac, C., Châtel, A., 2018. Investigating the establishment of primary cultures of hemocytes from Mytilus edulis. Cytotechnology. https://doi.org/ 10.1007/s10616-018-0212-x.

Bertrand, C., Devin, S., Mouneyrac, C., Giambérini, L., 2017. Eco-physiological responses to salinity changes across the freshwater-marine continuum on two euryhaline bivalves: Corbicula fluminea and Scrobicularia plana. Ecol. Indic. 74, 334-342. https:// doi.org/10.1016/j.ecolind.2016.11.029.

Canesi, Ciacci,C., Vallotto, D., Gallo, G., Marcomini, A., Pojana, G., 2010. In vitro effects of suspensions of selected nanoparticles (C60 fullerene, $\mathrm{TiO} 2, \mathrm{SiO} 2$ ) on Mytilus hemocytes. Aquat. Toxicol. 96, 151-158. https://doi.org/10.1016/j.aquatox.2009.10. 
017.

Canesi, L., Borghi, C., Ciacci, C., Fabbri, R., Lorusso, L.C., Vergani, L., Marcomini, A., Poiana, G., 2008a. Short-term effects of environmentally relevant concentrations of EDC mixtures on Mytilus galloprovincialis digestive gland. Aquat. Toxicol. 87, 272-279. https://doi.org/10.1016/j.aquatox.2008.02.007.

Canesi, L., Ciacci, C., Betti, M., Fabbri, R., Canonico, B., Fantinati, A., Marcomini, A., Pojana, G., 2008b. Immunotoxicity of carbon black nanoparticles to blue mussel hemocytes. Environ. Int. 34, 1114-1119. https://doi.org/10.1016/j.envint.2008.04 002 .

Cao, A., Mercado, L., Ramos-Martinez, J.I., Barcia, R., 2003. Primary cultures of hemocytes from Mytilus galloprovincialis Lmk.: expression of IL-2R $\alpha$ subunit. Aquaculture 216, 1-8. https://doi.org/10.1016/S0044-8486(02)00140-0.

Châtel, A., Lièvre, C., Barrick, A., Bruneau, M., Mouneyrac, C., 2018. Transcriptomic approach: a promising tool for rapid screening nanomaterial-mediated toxicity in the marine bivalve Mytilus edulis - application to copper oxide nanoparticles. Comp. Biochem. Physiol. Part C Toxicol. Pharmacol. 205, 26-33. https://doi.org/10.1016/j. cbpc. 2018.01.003.

Chevé, J., Bernard, G., Passelergue, S., Prigent, J.-L., 2014. Suivi bactériologique des gisements naturels de coquillages de l'Ille-et-Vilaine et des Côtes- d'Armor fréquentés en pêche à pied. pp. 1-99.

Cho, H.-W., Kim, S.B., Jeong, M.K., Park, Y., Miller, N.G., Ziegler, T.R., Jones, D.P., 2008. Discovery of metabolite features for the modelling and analysis of high-resolution NMR spectra. Int. J. Data Min. Bioinform. 2, 176-192.

Deloid, G.M., Cohen, J.M., Pyrgiotakis, G., Demokritou, P., 2017. Preparation, characterization, and in vitro dosimetry of dispersed, engineered nanomaterials. Nat. Protoc. 12, 355-371. https://doi.org/10.1038/nprot.2016.172.

Dubochet, J., Groom, M., Mueller-Neuteboom, S., 1982 . The mounting of macromolecules for Electron microscopy with particular reference to surface phenomena and the treatment of support films by glow discharge. Adv. Opt. Electron Microsc. 8, 107-135.

Fenwick, N., Griffin, G., Gauthier, C., 2009. The welfare of animals used in science: how the "three Rs" ethic guides improvements. Can. Vet. J. 50, 523-530.

Gagné, F., Auclair, J., Turcotte, P., Fournier, M., Gagnon, C., Sauvé, S., Blaise, C., 2008. Ecotoxicity of CdTe quantum dots to freshwater mussels: impacts on immune system, oxidative stress and genotoxicity. Aquat. Toxicol. 86, 333-340. https://doi.org/10. 1016/j.aquatox.2007.11.013.

Heise, T., Schug, M., Storm, D., Ellinger-Ziegelbauer, H., J. Ahr, H., Hellwig, B. Rahnenführer, J., Ghallab, A., Guenther, G., Sisnaiske, J., Reif, R., Godoy, P., Mielke, H., Gundert-Remy, U., Lampen, A., Oberemm, A., Hengstler, J.G., 2012. In vitro - in vivo correlation of gene expression alterations induced by liver carcinogens. Curr. Med. Chem. 19, 1721-1730. https://doi.org/10.2174/092986712799945049.

Hinderliter, P.M., Minard, K.R., Orr, G., Chrisler, W.B., Thrall, B.D., Pounds, J.G., Teeguarden, J.G., 2010. ISDD: a computational model of particle sedimentation, diffusion and target cell dosimetry for in vitro toxicity studies. Part. Fibre Toxicol. 7, 36. https://doi.org/10.1186/1743-8977-7-36.

Ivanova, M.V., Lamprecht, C., Jimena Loureiro, M., Torin Huzil, J., Foldvari, M., 2012 Pharmaceutical characterization of solid and dispersed carbon nanotubes as nanoexcipients. Int. J. Nanomedicine 7, 403-415. https://doi.org/10.2147/IJN. S27442.

Jaumot, J., Navarro, A., Faria, M., Barata, C., Tauler, R., Piña, B., 2015. qRT-PCR evaluation of the transcriptional response of zebra mussel to heavy metals. BMC Genomics 16. https://doi.org/10.1186/s12864-015-1567-4.

Jensen, K.A., Kembouche, Y., Christiansen, E., Jacobse, Nicklas R., Wallin, H.åkan, Giot,
C., Spalla, O., Witschger, O., 2011. Final protocol for producing suitable manufactured nanomaterial exposure media. NANoREG A common Eur. approach to Regul. Test. Nanomater. Web-Report.

Katsumiti, A., Berhanu, D., Howard, K.T., Arostegui, I., Oron, M., Reip, P., Valsami-Jones, E., Cajaraville, M.P., 2014. Cytotoxicity of TiO2 nanoparticles to mussel hemocytes and gill cells in vitro: influence of synthesis method, crystalline structure, size and additive. Nanotoxicology 5390, 1-11. https://doi.org/10.3109/17435390.2014. 952362.

Kraegeloh, A., Suarez-merino, B., Sluijters, T., Micheletti, C., 2018. Implementation of Safe-by-Design for Nanomaterial Development and Safe Innovation : Why We Need a Comprehensive Approach. https://doi.org/10.3390/nano8040239.

Matranga, V., Corsi, I., 2012. Toxic effects of engineered nanoparticles in the marine environment: model organisms and molecular approaches. Mar. Environ. Res. 76, 32-40. https://doi.org/10.1016/j.marenvres.2012.01.006.

Moore, M.N., 2006. Do nanoparticles present ecotoxicological risks for the health of the aquatic environment? Environ. Int. 32, 967-976. https://doi.org/10.1016/j.envint. 2006.06.014.

Moore, M.N., Readman, J.A.J., Readman, J.W., Lowe, D.M., Frickers, P.E., Beesley, A., 2009. Lysosomal cytotoxicity of carbon nanoparticles in cells of the molluscan immune system: an in vitro study. Nanotoxicology 3, 40-45. https://doi.org/10.1080/ 17435390802593057.

Pavlin, M., Bregar, V.B., 2012. Stability of nanoparticle suspensions in different biologically relevant media. Dig. J. Nanomater. Biostructures 7, 1389-1400.

R Studio Team, 2015. R Studio: Integrated Development for R.

Reinert, L., Zeiger, M., Suárez, S., Presser, V., Mücklich, F., 2015. Dispersion analysis of carbon nanotubes, carbon onions, and nanodiamonds for their application as reinforcement phase in nickel metal matrix composites. RSC Adv. 5, 95149-95159. https://doi.org/10.1039/C5RA14310A.

Revel, M., Châtel, A., Mouneyrac, C., 2017. Omics tools: new challenges in aquatic nanotoxicology? Aquat. Toxicol. 193, 72-85. https://doi.org/10.1016/j.aquatox.2017. 10.005 .

Schwarz-plaschg, C., Kallhoff, A., Eisenberger, I., 2017. Making Nanomaterials Safer by Design? pp. 277-281.

Snape, J.R., Maund, S.J., Pickford, D.B., Hutchinson, T.H., 2004. Ecotoxicogenomics: the challenge of integrating genomics into aquatic and terrestrial ecotoxicology. Aquat. Toxicol. 67, 143-154. https://doi.org/10.1016/j.aquatox.2003.11.011.

Vera-Agullo, J., Varela-Rizo, H., Conesa, J.A., Almansa, C., Merino, C., Martin-Gullon, I, 2007. Evidence for growth mechanism and helix-spiral cone structure of stacked-cup carbon nanofibers. Carbon 45, 2751-2758. https://doi.org/10.1016/j.carbon.2007. 09.040. N. Y.

Vitkina, T.I., Yankova, V.I., Gvozdenko, T.A., Kuznetsov, V.L., Krasnikov, D.V., Nazarenko, A.V., Chaika, V.V., Smagin, S.V., Tsatsakis, A.M., Engin, A.B., Karakitsios, S.P., Sarigiannis, D.A., Golokhvast, K.S., 2016. The impact of multi-walled carbon nanotubes with different amount of metallic impurities on immunometabolic parameters in healthy volunteers. Food Chem. Toxicol. 87, 138-147. https://doi.org/10. 1016/j.fct.2015.11.023

Weisenberger, M., Martin-Gullon, I., Vera-Agullo, J., Varela-Rizo, H., Merino, C., Andrews, R., Qian, D., Rantell, T., 2009. The effect of graphitization temperature on the structure of helical-ribbon carbon nanofibers. Carbon 47, 2211-2218. https:// doi.org/10.1016/j.carbon.2009.03.070. N. Y.

Ye, S.F., Wu, Y.H., Hou, Z.Q., Zhang, Q.Q., 2009. ROS and NF-кB are involved in upregulation of IL-8 in A549 cells exposed to multi-walled carbon nanotubes. Biochem. Biophys. Res. Commun. 379, 643-648. https://doi.org/10.1016/j.bbrc.2008.12.137. 